TILTAI, 2021,2, 1-13 ISSN 1392-3137 (Print), ISSN 2351-6569 (Online); DOI: 10.15181/tbb.v87i2.2314

\title{
THE TRANSITION FROM EDUCATION TO THE LABOUR MARKET DURING THE COVID-19 PANDEMIC: THE ATTITUDES AND EXPERIENCES OF UNEMPLOYED YOUTH IN LITHUANIA
}

\author{
Rūta Brazienė, Boguslavas Gruževskis, Laima Okunevičiūtė-Neverauskienė \\ Lithuanian Social Science Centre, Institute of Sociology (Lithuania)
}

\begin{abstract}
This paper presents a subjective evaluation of the attitudes and experiences in the Lithuanian labour market of currently unemployed youths (aged 18 to 35) registered at the public employment service (PES). The main focus is on identifying the main issues related to the successful transition of youths from education to the labour market. Research questions: How do currently unemployed young people evaluate their prospects on the labour market? What is the impact of the Covid-19 pandemic on youth transitions? What are the obstacles in the search for a (first) job? The study is based on survey research that was carried out in Lithuania from February to April 2021. A total of 453 young people who are currently unemployed and registered at the PES participated in the study. The results reveal that the Covid-19 pandemic has affected more vulnerable young people with a lower educational level and less work experience living in rural areas. Respondents with lower levels of education indicated greater difficulties in the search for a first job and in obtaining a stable working position. The Covid-19 pandemic has affected the transition from education to the labour market for young women more than for men.

KEY WORDS: unemployed youth, transition from education to the labour market, impact of the Covid-19 pandemic on youth employment.
\end{abstract}

\begin{abstract}
Anotacija
Straipsnyje pristatomas šiuo metu nedirbančio ir užimtumo tarnyboje registruoto jaunimo (18-35 metų amžiaus) subjektyvus patirties ir galimybių darbo rinkoje vertinimas. Pagrindinis dèmesys skiriamas problemoms, kurios susijusios su sẻkmingu jaunimo perèjimu iš išsilavinimo pakopos ị darbo rinką. Tyrimo klausimai: kaip šiuo metu nedirbantis jaunimas vertina savo galimybes darbo rinkoje Lietuvoje; koks yra COVID-19 pandemijos poveikis jaunimo perejjimui iš švietimo sistemos ị darbo rinką; kokios yra darbo paieškos kliūtys? Šis tyrimas remiasi $2021 \mathrm{~m}$. vasario-balandžio mènesiais atlikta jaunimo apklausa, kurioje dalyvavo 453 šiuo metu nedirbantys ir užimtumo tarnyboje registruoti asmenys. Atlikto tyrimo rezultatai atskleide, kad COVID-19 pandemija paveikè labiau pažeidžiamus jaunus žmones, turinčius menkesnị išsilavinimą ir darbo patirtį, gyvenančius kaimo vietovèse. Menkesnị išsilavinimą turintys respondentai labiau akcentavo sunkumus ieškant (pirmojo) darbo ir surandant stabilias darbo vietas. COVID-19 pandemija labiau paveike jaunų moterų, palyginti su vyrais, perejjimą iš švietimo sistemos ị darbo rinką.

PAGRINDINIAI ŽODŽIAI: nedirbantis jaunimas, perẻjimas iš švietimo sistemos ị darbo rinką, COVID-19 pandemijos poveikis jaunimo dalyvavimui darbo rinkoje.
\end{abstract}

DOI: http://dx.doi.org/10.15181/tbb.v87i2.2314 
Rūta Brazienė, Boguslavas Gruževskis, Laima Okunevičiūtè-Neverauskienė

\section{Introduction}

Social and economic changes, the expansion of higher education and skills-based technological progress have changed the youth labour market, and the schoolto-work transition has become more complex, as clear and normative linear life trajectories no longer characterise young people's movement through education, work and personal relationships (EGRIS, 2001). In many European countries, the successful transition by youth from education to the labour market has been a central issue of social policy. Comparative research has shown that labour market insecurities affect young people significantly in many European countries. Young people often experience periods of unemployment, a lack of a stable working position, and decent working conditions (Gebel et al., 2021; Eurofound, 2021; Karamessini et al., 2019; Passaretta, Wolbers, 2019; etc). Economic globalisation and social transformation have resulted in increased uncertainty for you on the labour market (Blossfeld et al., 2005).

The transitions and situation of young people on the labour market are particularly affected by crises: socio-economic crises such as the 2008 financial crisis, and the current crisis caused by the Covid-19 pandemic (ILO, 2021; Eurofound, 2021; OECD, 2021; etc). Socio-economic crises have had a particularly negative impact on young people in the labour market and on their transition from education to the labour market (Eurofound, 2021). The Covid-19 pandemic has had a negative impact not only on youth employment levels but also on working conditions, and it affects young people's search for a job and employability, making them an even more vulnerable group on the labour market (ILO, 2021; Eurofound, 2021; OECD, 2021 ; etc). In particular, the Covid-19 crisis has hit socially vulnerable groups of young people (unemployed young people, NEET youth, young people in nonstandard employment, temporary workers, workers in atypical employment, etc).

Youth employment declined in Lithuania more significantly than the average in the EU-27. The lockdown that started in the country in March 2020 was followed by an increase in unemployment of workers of all age groups, but we observed in particular an increase in unemployment among young people (18 to 35 years old). For example, according to Lithuanian statistics, youth unemployment increased from $6.3 \%$ in December 2019 to $18.3 \%$ in January 2021.

The successful transition of youth from education to the labour market is the subject of strategic policy documents. The National Youth Policy Development Programme 2011-2019 is one of the main documents which define the most important features of contemporary and future youth policy in the country. The programme defines the main aspects of youth employment policy. Its primary aim is to provide possibilities for young people to become active and motivated citizens in modern 
society, by improving the social security, education and health systems. Another document that stresses the successful transition of youth from education to the labour market is the Strategy for Demography, Migration and Integration Policy 2018-2030. The need to strengthen the smooth transition from education to the labour market through active labour market policies for young people is pointed out, in order to reduce the high levels of youth emigration.

This paper presents a subjective evaluation of youth (aged 18 to 35) currently unemployed and registered at the Lithuanian public employment service (PES), about their experiences and prospects on the Lithuanian labour market. The main focus lies in identifying major issues relating to the successful transition of youth from education to the labour market. Research questions: How do currently unemployed young people evaluate their prospects on the labour market? What is the impact of the Covid-19 pandemic on youth transitions? What are the obstacles to a (first) job, and the search for a job in general? The study is based on survey research that was carried out in Lithuania in February and April 2021. A total of 453 young people currently unemployed and registered at the Lithuanian public employment service (PES) participated in the study.

Research methods: analysis of scientific literature, survey research, quantitative data analysis.

\section{Theoretical background}

The concept of the transition of youth from education to the labour market. Research literature presents numerous concepts of the transition of youth from school to the labour market (Gebel, 2020; Brzinsky-Fay, 2013; 2011; ILO, 2009; Elder, 2009; Marchetti et al., 2001; etc). The transition from school to work has been described as a dynamic process, in which a person moves from the education system to a relatively stable working position (Marchetti et al., 2001). The International Labour Organisation (ILO) describes the transition from education to the labour market as a period between the completion of learning and the first permanent/decent work (ILO, 2009).

There are myriad studies of the transition of youth from education to the labour market; and many different ways of evaluating the quality of transitions from education to the labour market have been considered in scientific literature (Gebel et al., 2021; Gebel, 2020; Brazienè, 2020; Baranowska-Rataj et al., 2017; BrzinskyFay, 2013; etc). A considerable body of research on youth transitions focuses on the duration of the first job, and whether the person finds a job immediately after leaving education, or experiences periods of unemployment, etc. The transition from education to the labour market is also described as achieving a status or 
Rūta Brazienė, Boguslavas Gruževskis, Laima Okunevičiūtè-Neverauskienė

position on the labour market during a certain period of time (ILO 2009). Most research on the transition from education to the labour market defines this period as between the exit of youth (15 to 29 years old) from the education system (the acquisition of an appropriate education or completed training/study) and the first search for a proper job. There have been a lot of changes in recent years to the definition of a first job. The most common definition of a first job describes it as 'the first significant work, in which a person worked for at least six months or a year', excluding short periods of employment in temporary jobs (ILO, 2009).

The transition of youth from education to the labour market is a complex multidimensional phenomenon, determined by multiple interacting factors. Research in different East and West European countries has highlighted the central role of educational qualifications for the integration of youth into the labour market (Braziene, 2020; Gebel, 2020; Saar, 2008; Ryan, 1999; Müller, Shavit, 1998; etc). The situation of youth in the education system, the opportunities to gain professional experience during studies, is the core aspect that influences the employment possibilities of youth in the future (Braziene, Mikutavičienè, 2013). Other significant individual-level factors include gender, social capital, family status, etc (Versnel, 2011; Engeström, 2001; Putnam, 2001; Laroche et al., 1999; etc). As young people are a social group that is particularly vulnerable to fluctuations in employment opportunities (Gebel et al., 2021; Baranowska-Rataj et al., 2017; etc), it is important to mention macro level factors, e.g. social and economic transformations and demographic changes. A considerable number of young people face a higher risk of unemployment in comparison with the rest of the adult population. Most problems are related to a lack of work experience, a lack of the necessary qualifications, and difficult transitions from education to working life. The mismatch between education and labour supply determines the number of over-qualified and under-qualified youth who are not able to find an appropriate job.

A number of different indicators are used to measure the transition of youth from education to the labour market. The first standard indicators should be mentioned, i.e. the youth employment rate, the youth unemployment rate, the youth activity rate, the average time it takes for a young person to move into employment after completing training or studies, youth employment status, the number of young unemployed, etc. Eurostat indicators can be classified into the following groups: quantitative indicators (activity rate, unemployment rate, employment rate, etc); duration of unemployment (the period of time in which a suitable job is found); and the mobility transition from employment to a different status in the labour market. For the analysis of the transition of young people from the education system to the labour market, researchers make extensive use of indicators of the length of entry into the labour market (Leuze, 2011), the first suitable job (Wolbers, 2007), etc. The work of West 
European researchers is largely dominated by the analysis of secondary, quantitative data, with frequent comparisons between countries, different generations, cohorts, different time periods, etc. Eurostat LFS labour force survey data are very widely used (Brzinsky-Fay, 2013; Brzinsky-Fay, 2011; Wolbers, 2007; etc).

As a response to the Covid-19 pandemic, different countries have introduced new plans and strategies, and made commitments. The responses differ significantly between countries, both in scale and area of focus, but several directions of measures can be identified (Eurofound, 2021). A number of countries introduced special emergency schemes: income support for young people, hiring subsidies for employers recruiting young people, new apprenticeship schemes, lower minimum contribution requirements for young people to get access to social security benefits (COVID-19 EU PolicyWatch; OECD, 2021; etc). The Youth Guarantee scheme (the reinforced Youth Guarantee, 2021), under which EU member states provide all young people under 30 years of age with employment, education, an apprenticeship or a traineeship within four months of either leaving education or becoming newly unemployed, was reinforced to respond better during the pandemic. All EU countries have committed themselves to the implementation of the reinforced Youth Guarantee scheme, which 'steps up the comprehensive job support available to young people across the European Union, now reaching out to a broader target group of 15 to 29-year-olds' (the reinforced Youth Guarantee, 2021).

\section{Data and methods}

This study is based on survey research that was carried out between February and April 2021. A total of 453 young people (aged 18 to 35), who are currently unemployed and registered at the Lithuanian public employment service (PES, participated in the study. The collection of data was carried out by using computer-assisted web interviewing (CAWI). The collection of the survey data was carried out in compliance with all ethical and other standards for research quality according to the World Association for Public Opinion Research (WAPOR) and the European Society for Opinion and Marketing Research (ESOMAR) for researchers that are members of researchers' organisations. The survey questionnaire was based on a previous survey instrument that was developed by implementing a survey on the transition of youth from education in Lithuania (Braziene, 2020; Braziene, Merkys, 2013; etc). The research instrument is aimed at showing the main challenges for the transition of youth from education to the labour market. The survey instrument consists of a total of 262 indicators. Only some of the data from the survey is used in this paper. 
The main dimensions of the survey instrument are the following: educational background (educational achievements, educational choices, participation in training/seminars), employment history (transition time from school to the labour market, first job characteristics/experience, first job search obstacles), work experience, the (mis)match between work position and education acquired (if any), the impact of the Covid-19 pandemic on the employment situation, the role of private and public employment services in the search for work, and socio-demographic and household characteristics.

The average age of the respondents was 24.6: the youngest respondent was 18 , and the oldest was 34 . The largest group of respondents, $32.6 \%$, had a secondary education, $26.5 \%$ had a vocational education, and $5.7 \%$ had a primary/basic education. Out of the remaining respondents, $20.4 \%$ had tertiary, $11.3 \%$ tertiary (professional, BA), and 3.6\% tertiary (MA) education. In comparison with the general population aged 18 to 35 , the respondents had a lower level of education. According to the place of residence, $22.3 \%$ of the respondents resided in the capital, 35.5\% in larger cities (Kaunas, Klaipėda, Šiauliai, Panevèžys), $26.5 \%$ in other cities, and $15.7 \%$ of respondents resided in rural areas. All the participants that participated in the study had at least some work experience. The duration of the work experience varied from up to three months to two to five years. The majority of respondents $(30.9 \%)$ had work experience of up to a few years (for a more detailed, see picture 1).

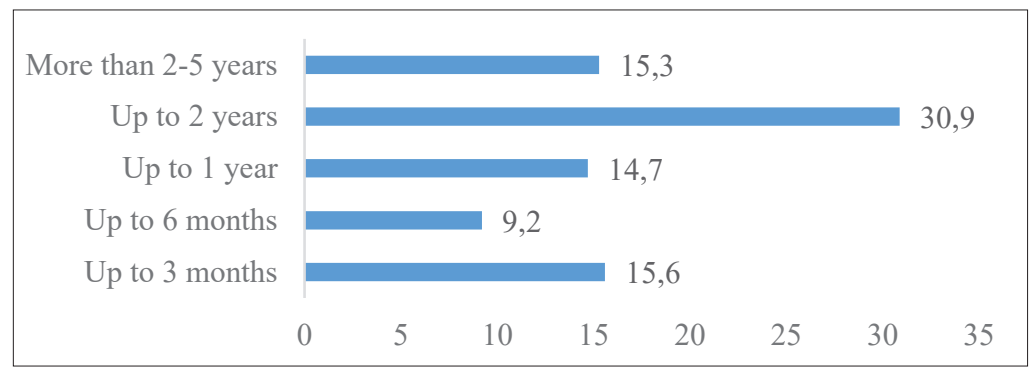

Figure 1. Respondents according to the duration of work experience, $N=453, \%$

\section{Discussion of the results}

Experience in the first/previous job. The transition of youth to a (first) job is a very important experience for successful integration into the labour market. According to the survey results, $66.6 \%$ of the respondents indicated that the 
first job did not match or almost did not match the education and profession acquired. Only a small part (11.6\%) indicated that the first job matched the education acquired. About a fifth of the respondents (21.8\%) indicated that their first job partly matched the education and profession acquired. The education level plays an important role in the match to the education attained ( $p=0.000$, ANOVA). The lower the level of education attained, the less likely the work will match the education attained. The strongest skill mismatch effect occurs when young people enter the labour market for the first time. However, it affects individuals at different stages in their working life as well, especially when they are trying to reach higher career prospects, change work places, or re-enter the labour market after a period of temporary or permanent unemployment.

Young people apply different strategies to the search for a job. Most respondents indicated that they get their first job by competition in an organisation (38.2\%). The role of a personal network also had a positive impact on the first employment for respondents to the survey. Parents of other relatives, friends and acquaintances supported young people in the search for a first job (for more detail, see Picture 2). The support of parents and other relatives was more relevant for younger respondents $(p=0.005$, ANOVA).

The difficulties in the first job reflect a young person's adaptation problems in the workplace. Based on an analysis of the results of the study, the main reasons that prevent young people from finding a job are related to how well young people are prepared to integrate into the labour market, e.g. the appropriate education, a profession in demand, and work experience. An important aspect is the remuneration for the work. Almost half the respondents (44\%) indicated that the salary was too low for the hard work (for more detail, see Table 1).

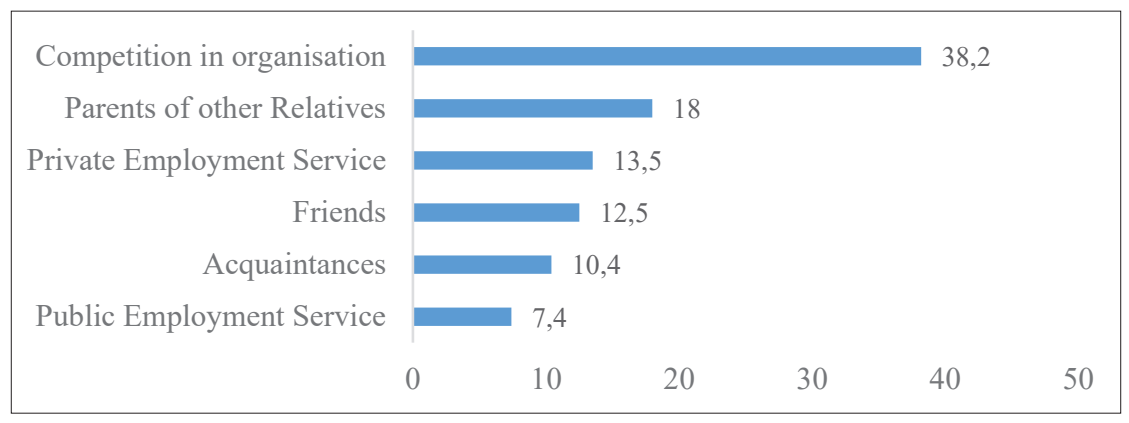

Figure 2. How did you get your first job? $N=453, \%$ 
Rūta Brazienė, Boguslavas Gruževskis, Laima Okunevičiūtè-Neverauskienė

Table 1. Difficulties in the first job, $N=453, \%$

\begin{tabular}{|l|l|l|l|l|l|}
\hline & $\begin{array}{l}\text { Completely } \\
\text { agree / } \\
\text { agree }\end{array}$ & $\begin{array}{l}\text { Neither } \\
\text { agree, } \\
\text { nor dis- } \\
\text { agree }\end{array}$ & $\begin{array}{l}\text { Com- } \\
\text { pletely } \\
\text { disagree/ } \\
\text { disagree }\end{array}$ & $\begin{array}{l}\text { M } \\
\text { (average) }\end{array}$ & Sd \\
\hline $\begin{array}{l}\text { The job was physically } \\
\text { very hard }\end{array}$ & 38.0 & 20.1 & 41.8 & 2.86 & 1.405 \\
\hline I lacked practical skills & 30.0 & 13.5 & 50.6 & 2.56 & 1.276 \\
\hline $\begin{array}{l}\text { I lacked theoretical knowl- } \\
\text { edge }\end{array}$ & 17.2 & 22.8 & 60.0 & 2.27 & 1.163 \\
\hline I lacked teamwork skills & 15.2 & 17.8 & 67.0 & 2.14 & 1.161 \\
\hline $\begin{array}{l}\text { I lacked communication } \\
\text { skills }\end{array}$ & 17.0 & 13.5 & 67.1 & 2.09 & 1.177 \\
\hline $\begin{array}{l}\text { I was controlled too much } \\
\text { by an employer }\end{array}$ & 29.0 & 25.4 & 45.6 & 2.69 & 1.323 \\
\hline $\begin{array}{l}\text { My salary was very low, } \\
\text { and I needed to work very } \\
\text { hard }\end{array}$ & 44.0 & 20.0 & 36.0 & 3.1 & 1.37 \\
\hline
\end{tabular}

Regarding the main obstacles that prevented finding a stable work position, the respondents indicated the lack of work experience, the lack of a suitable education $(50.6 \%)$, the low level of salaries offered $(51.5 \%)$, the lack of a marketable profession (43.0\%), and the inability to find the desired job (44.1\%). According to information provided by the Lithuanian public employment service (PES), many youths lack professional qualifications. For example, in 2020, $45 \%$ of young people registered at the public employment service lacked professional qualifications (in comparison with all registered unemployed, 31.5\% lack a professional qualification). Also, in 2020, the largest share (56.1\%) of registered unemployed young people was those with a secondary education. The share of those with a higher education among unemployed youth was $23.8 \%$.

Table 2. The main obstacles to finding a stable work position, $N=453, \%$

\begin{tabular}{|l|l|l|l|l|l|}
\hline & $\begin{array}{l}\text { Complete- } \\
\text { ly agree/ } \\
\text { agree }\end{array}$ & $\begin{array}{l}\text { Neither } \\
\text { agree, } \\
\text { nor dis- } \\
\text { agree }\end{array}$ & $\begin{array}{l}\text { Com- } \\
\text { pletely } \\
\text { dis- } \\
\text { agree/ } \\
\text { disagree }\end{array}$ & $\begin{array}{l}\text { M } \\
\text { (ave- } \\
\text { rage) }\end{array}$ & Sd \\
\hline $\begin{array}{l}\text { Difficulties matching work to } \\
\text { studies }\end{array}$ & 39.4 & 15.2 & 45.4 & 2.85 & 1.451 \\
\hline I do not have a suitable education & $\mathbf{5 0 . 6}$ & 22.5 & 26.9 & 3.29 & 1.276 \\
\hline $\begin{array}{l}\text { I do not have a marketable profes- } \\
\text { sion }\end{array}$ & $\mathbf{4 3 . 0}$ & 29.2 & 27.9 & 3.2 & 1.233 \\
\hline
\end{tabular}


THE TRANSITION FROM EDUCATION TO THE LABOUR MARKET DURING THE...

\begin{tabular}{|l|l|l|l|l|l|}
\hline & $\begin{array}{l}\text { Complete- } \\
\text { ly agree/ } \\
\text { agree }\end{array}$ & $\begin{array}{l}\text { Neither } \\
\text { agree, } \\
\text { nor dis- } \\
\text { agree }\end{array}$ & $\begin{array}{l}\text { Com- } \\
\text { pletely } \\
\text { dis- } \\
\text { agree/ } \\
\text { disagree }\end{array}$ & $\begin{array}{l}\text { M } \\
\text { (ave- } \\
\text { rage) }\end{array}$ & Sd \\
\hline $\begin{array}{l}\text { The demand is low on the labour } \\
\text { market }\end{array}$ & 20.3 & 26.8 & 52.9 & 3.46 & 1.128 \\
\hline I do not have work experience & $\mathbf{6 6 . 3}$ & 12.3 & 21.4 & 3.7 & 1.279 \\
\hline $\begin{array}{l}\text { I cannot find a job that I would } \\
\text { like }\end{array}$ & $\mathbf{4 4 . 1}$ & 27.0 & 28.9 & 3.21 & 1.217 \\
\hline I do not have the demand to work & 3.6 & 10.5 & 85.8 & 1.7 & 0.859 \\
\hline $\begin{array}{l}\text { I am taking care of an elderly } \\
\text { relative }\end{array}$ & 7.3 & 4.6 & 88.1 & 1.54 & 0.937 \\
\hline I am taking care of small children & 14.9 & 6.5 & 78.6 & 1.81 & 1.26 \\
\hline The proposed salaries are too low & $\mathbf{5 1 . 5}$ & 24.4 & 24.1 & 3.39 & 1.228 \\
\hline $\begin{array}{l}\text { Discrimination due to gender, dis- } \\
\text { ability, sexual orientation, etc }\end{array}$ & 17.3 & 22.1 & 60.6 & 2.3 & 1.266 \\
\hline
\end{tabular}

A considerable number of young people lack work experience, skill in searching for a job, and the financial and social resources to find suitable employment. The situation of young people on the labour market is made particularly tenuous not only by the high rate of unemployment and inactivity in the country, but also by the changing conditions on the labour market. The mismatch between the qualifications available to young people and the demands of the labour market complicates the transition from education to the labour market, as does the reluctance of employers to recruit young people without previous work experience or the necessary skills. According to the opinions of the respondents, there is a set of skills for successful employment that are most important to get a decent job. Among the most important characteristics are: knowledge of foreign languages (89.8\%), ICT skills (82.9\%), communication skills (91\%), and teamwork skills (87.3\%) (for more detail, see Table 3).

Table 3. The most important characteristics to get a decent job, $N=453, \%$

\begin{tabular}{|l|l|l|l|l|l|}
\hline & $\begin{array}{l}\text { Completely } \\
\text { agree/agree }\end{array}$ & $\begin{array}{l}\text { Neither } \\
\text { agree, nor } \\
\text { disagree }\end{array}$ & $\begin{array}{l}\text { Com- } \\
\text { pletely } \\
\text { disagree/ } \\
\text { disagree }\end{array}$ & $\begin{array}{l}\text { M (av- } \\
\text { erage) }\end{array}$ & Sd \\
\hline A higher education & 62.5 & 19.6 & 17.8 & 3.59 & 1.149 \\
\hline $\begin{array}{l}\text { The acquired profession in } \\
\text { demand on the market }\end{array}$ & 72.4 & 19.3 & 8.3 & 3.87 & 1.019 \\
\hline ICT skills & $\mathbf{8 2 . 9}$ & 10.3 & 6.4 & 4.03 & 0.904 \\
\hline
\end{tabular}


Rūta Brazienė, Boguslavas Gruževskis, Laima Okunevičiūtè-Neverauskienė

\begin{tabular}{|l|l|l|l|l|l|}
\hline & $\begin{array}{l}\text { Completely } \\
\text { agree/agree }\end{array}$ & $\begin{array}{l}\text { Neither } \\
\text { agree, nor } \\
\text { disagree }\end{array}$ & $\begin{array}{l}\text { Com- } \\
\text { pletely } \\
\text { disagree/ } \\
\text { disagree }\end{array}$ & $\begin{array}{l}\text { M (av- } \\
\text { erage) }\end{array}$ & Sd \\
\hline $\begin{array}{l}\text { A high professional qualifica- } \\
\text { tion and competence }\end{array}$ & 77.2 & 16.3 & 6.5 & 3.99 & 0.949 \\
\hline $\begin{array}{l}\text { Knowledge of foreign lan- } \\
\text { guages }\end{array}$ & $\mathbf{8 9 . 9}$ & 7.3 & 2.9 & 4.29 & 0.805 \\
\hline Leadership & 57.0 & 33.7 & 9.3 & 3.61 & 0.978 \\
\hline Business knowledge & 58.6 & 32.9 & 8.5 & 3.64 & 0.958 \\
\hline Communication skills & $\mathbf{9 1 . 0}$ & 5.6 & 3.4 & 4.35 & 0.815 \\
\hline Teamwork skills & $\mathbf{8 7 . 3}$ & 9.9 & 2.9 & 4.24 & 0.805 \\
\hline A respectable appearance & 60.4 & 28.6 & 10.9 & 3.64 & 0.992 \\
\hline Personal ambition & 77.3 & 16.9 & 5.7 & 4.03 & 0.951 \\
\hline Useful relationships/contacts & 71.1 & 19.9 & 9.1 & 3.92 & 1.059 \\
\hline
\end{tabular}

The Covid-19 pandemic affected the labour market and youth employment very significantly. It is evident from our study that the Covid-19 pandemic has had a significant impact on youth employment, and has generally worsened the situation on the labour market. Almost half the respondents (44.3\%) indicated that their situation on the labour market had worsened (for more detail, see Figure 3).

It is evident from the study that young women ( $p=0,000$, ANOVA), the less educated ( $p=0,003$, ANOVA), and young people living in rural areas $(p=0,005$, ANOVA), were affected more by the Covid-19 pandemic. The vulnerability of young people on the labour market during the Covid-19 pandemic is related to the fact that young people have lower levels of job security and are at greater risk of losing their job, and to sectoral job vacancy rates. The main losses are in sectors that employ a large proportion of young people with temporary contracts (Eurofound, 2021).

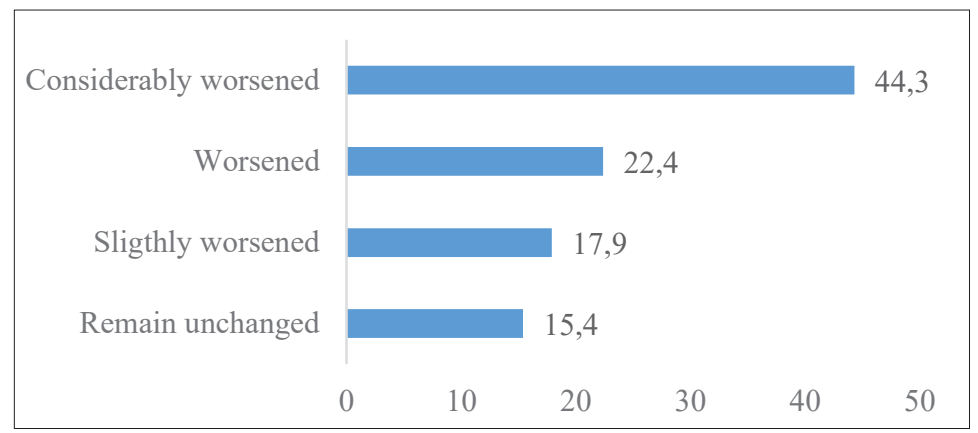

Figure 3. The impact of the Covid-19 pandemic on youth employment, $N=453, \%$ 


\section{Conclusions}

The transition from the education system to the labour market can be defined by a complex of factors, i.e. the result of the interaction of macro-factors (features of the education system, the nature of the economy and the peculiarities of the labour market, labour market formation policy, the demographic structure of the country, etc) and individual characteristics (competences, motivation, experience, etc).

Our study aimed to investigate how young people who are currently unemployed and registered at the PES evaluate their prospects on the labour market in Lithuania, and what the impact of the Covid-19 pandemic on the transition of youth from education to the labour market has been. A survey was carried out of young people currently registered at the Lithuanian public employment service (PES). Among the most important requirements to get a decent job are: ICT skills, knowledge of foreign languages, and good communication skills.

It is evident from the different studies (ILO, 2021; Eurofound, 2021; etc) that the impact of the Covid-19 pandemic on young people's livelihoods has been more severe than for older adults; young people are less protected by job retention, income support, subsidised wages, and other welfare schemes. The results of our research have revealed that the Covid-19 pandemic has affected more vulnerable young people with a lower educational level and less work experience, and those living in rural areas. Respondents with a lower level of education indicated greater difficulties in the search for a first job, and in obtaining a stable work position. The Covid-19 pandemic has affected the transition from education to the labour market of young women more than men.

\section{References}

Baranowska-Rataj, A., Bertolini, S., Goglio, V. (eds.). (2017). Country level analyses of mechanisms and interrelationships between labour market insecurity and autonomy. EXCEPT Working Papers, WP No 11. Tallinn University.

Brazienè, R. (2020). Youth Transition from Education to the Labour Market in Lithuania: The Role of the Youth and Parental Education. The Annals of the American Academy of Social and Political Science, Vol. 688, Issue 1, p. 155-170. Available on line: http://journals.sagepub.com/home/ann.

Blossfeld, H. P., Klijzing, E., Mills, M., Kurz, K. (eds.). (2005). Globalization, Uncertainty and Youth in Society. London: Routledge.

Brazienè, R., Merkys, G. (2013). „Lietuvos jaunimo perejjimas iš švietimo sistemos ị darbo rinką: teorinès prielaidos ir empiriniai radiniai“. Filosofija. Sociologija = Philosophy. Sociology / Lietuvos mokslu akademija, Nr. 24 (2), p. 82-91. ISSN 0235-7186. ISI Web of Science, SocINDEX with Full Text, The Philosopher's Index, CSA Sociological Abstracts, CEEOL.

Brazienė, R., Mikutavičienè, I. (2013). Lietuvos jaunimo perèjimas iš švietimo sistemos ị darbo rinką: švietimo, darbo ir užimtumo politikos aspektas. Viešoji politika ir administravimas, T. 12, Nr. 1, p. 108-119.

Brzinsky-Fay, Chr. (2013). The Measurement of School-to-Work Transition as Processes. About Events and Sequences. European Societies. Available on line: http://www.tandfonline.com/doi/pdf/10.1080/14616696. 2013.821620 


\section{Rūta Brazienè, Boguslavas Gruževskis, Laima Okunevičiūtė-Neverauskienė}

Brzinsky-Fay, Chr. (2011). What Difference Does It Make? The Outcome Effects of the European Employment Strategy on the Transition from Education to Work. German Policy Studies, Vol. 7, No. 1, p. 45-72.

Brzinsky-Fay, Chr. (2008). Get the Balance Right. Risk and Flexibility in School-to-Work Transition Sequences. In P. Ester, R. Muffels, J. Schippers, T. Wilthagen (eds.). Innovating European Labour Markets. Dynamics and Perspectives. Cheltenham / Northampton, MA: Edward Elgar, p. 275-296.

Buchholz, S., Blossfeld, H. P. (2012). Changes in the economy, the labor market, and expectations for the future: what might Europe and the United States look like in twenty-five years? New directions for youth development, Vol. 135, p. 17-26.

COVID-19 EU PolicyWatch. (2020). Eurofound. Available on line: https:/www.eurofound.europa.eu/data/covid19-eu-policywatch/database.

Eurofound. (2021). Living and working in Europe 2020. Publications Office of the European Union, Luxembourg.

European Parliament. (2021). Youth in Europe: Effects of COVID-19 on their economic and social situation. Available on line: https://bit.ly/3wl7Hpr

Elder, S. (2009). ILO school-to-work transition survey: A methodological guide. Module 5, Disseminating survey results.

Buchholz, S., Kolb, K., Hofäcker, D., Blossfeld, H. P. (2011). Globalized labour markets and social inequality in Europe: theoretical framework. New York: Palgrave Macmillan.

Engeström, Y. (2001). Activity theory and social capital. Technical reports, University of Helsinki, Department of Education, Center for Activity Theory and Developmental Work Research.

Gebel, M., Unt, M., Bertolini, S., Deliyanni-Kouimtzis, V., Hofäcker, D. (2021). Introduction: Youth transitions in times of labour market insecurity. In M. Unt, M. M. Gebel, S. Bertolini, V. Deliyanni-Kouimtzi, D. Hofäcker (eds.). Social exclusion of youth in Europe. The multifaceted consequences of labour market insecurity. Bristol: The Policy Press, p. 1-27.

Gebel, M. (2020). Young women's transition from education to work in the Caucasus and Central Asia. The ANNALS of the American Academy of Political and Social Science, Vol. 688(1), p. 137-154.

Karamessini, M., Symeonaki, M., Stamatopoulou, G., Parsanoglou, D. (2019). Mapping early job insecurity impacts of the crisis in Europe. In B. Hvinden, C. Hyggen, M. A. Schoyen, T. Sirovátka (eds.). Youth Unemployment and Job Insecurity in Europe. Problems, Risk Factors and Policies. Cheltenham / Northampton: Edward Elgar Publishing, p. 24-44.

International Labour Organization. (2009). ILO school-to-work transition survey: a methodological guide. Geneva.

ILO. Decent Jobs for Youth. (2020). Youth \& COVID-19: Impacts on jobs, education, rights, and mental wellbeing. Geneva: International Labour Organisation. Available on line: https://bit.ly/3CSqXGX

Klijzing, E. (2005). Globalization in the early life course. A description of selected economic and demographic trends. In H. P. Blossfeld, E. Klijzing, M. Mills, K. Kurz (eds.). Globalization, uncertainty and youth in society. Oxon: Routledge, p. 24-46.

Laroche, M., Merette, M., Ruggeri, G. C. (1999). On the Concept and Dimensions of Human Capital in a Knowledge-Based Economy Context. Canadian Public Policy, p. 87-100.

Marchetti, M. P., Light, T. S., Feliciano, J., Armstrong, T. W., Hogan, Z., Moyle, P. B. (2001). Physical Homogenization and Biotic Homogenization in Aquatic Systems. In J. L. Lockwood, M. L. McKinney (eds.). Biotic Homogenization: The Loss of Diversity Through Invasion and Extinction, p. 259-278. Kluwer Academic Publishers: New York.

Müller, W., Shavit, Y. (1998). An institutional embeddedness of the stratification process: A comparative study of qualifications and occupations in thirteen countries. In Y. Shavit, W. Müller (eds.). From school to work. A comparative study of educational qualifications and occupational destinations, p. 1-48. New York, NY: Clarendon Press.

Passaretta, G., Wolbers, M. H. J. (2019). Temporary employment at labour market entry in Europe: labour market dualism, transitions to secure employment and upward mobility. Economic and Industrial Democracy, Vol. 40(2), p. 382-408.

Putnam, R. D. (2001). Social capital: Measurement and consequences. Canadian Journal of Policy Research, Vol. 2, p. 41-51.

Reitzle, M., Silbereisen, R. K. (2000). The timing of adolescents' school-to-work transition in the course of social change: The example of German unification. Swiss Journal of Psychology, Vol. 59, p. 240-255.

Ryan, P. (1999). The school-to-work transition: issues for further investigation. Education and Training Division, DEELSA, OECD, Paris. International sociology, 2008, Vol. 23, p. 561-595. 
Saar, E., Unt, M., Kogan, I. (2008). Transition from Educational System to Labour Market in the European Union: A Comparison between New and Old Members. International Journal of Comparative Sociology, Vol. 49(1), p. 31-59.

The Reinforced Youth Guarantee. (2021). European Commission. Available on line: https://bit.ly/3o85IAO

Versnel, J. et al. (2011). International and National factors affecting school-to-work transition for at-risk youth in Canada: an integrative review. The Canadian Journal of Career development, Vol. 10 (1), p. 21-31.

Wolbers, M. (2007). Employment Insecurity at Labour Market Entry and its Impact on Parental HomeLeaving and Family Formation: A Comparative Study among Recent Graduates in Eight European Countries. International Journal of Comparative Sociology, p. 481-507.

Rūta Brazienė - chief researcher, doctor of Social Sciences (Sociology), Department of Labour Market Studies, Institute of Sociology, Lithuanian Centre of Social Sciences

E-mail: ruta.braziene@dsti.lt 